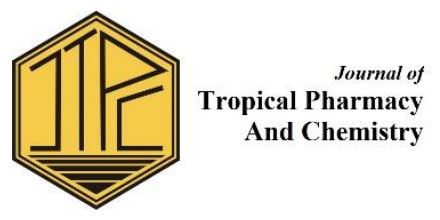

\title{
Effect of Ethanol Extract of Eleutherine bulbosa (Mill.) Urb on Anaerobic Bacterial Prophyromonas gingivalis in vitro
}

\author{
Siti Nur Azizah ${ }^{1, *}$, Sinar Yani ${ }^{2}$, Sjarif Ismail $^{3,4, *}$, Masyhudi $^{1,5}$, Endang Sawitri $^{6}$ \\ ${ }^{1}$ Dentistry Study Programe, Faculty of Medicine, Mulawarman University, Indonesia \\ ${ }^{2}$ Oral Biology Laboratory, Dentistry Study Programe, Faculty of Medicine, Mulawarman \\ University, Indonesia \\ ${ }^{3}$ Pharmacology Laboratory, Faculty of Medicine, Mulawarman University, Indonesia \\ ${ }^{4}$ Research Center on Drugs and Public Health, Mulawarman University, Indonesia \\ ${ }^{5}$ Laboratory of Microbiology, Faculty of Medicine, Mulawarman University, Indonesia \\ ${ }^{6}$ Physiology Laboratory, Faculty of Medicine, Mulawarman University, Indonesia \\ *Corresponding author email: sitinurazizah24101995@gmail.com and \\ ismail8997@yahoo.com
}

\begin{abstract}
Periodontitis is an inflammation of supporting tissues on teeth that became the main cause of Prophyromonas gingivalis ( $P$. gingivalis) bacteria. Treatment of periodontitis is by giving antibacterial agent therapy. Plants that have antibacterial effects one are Eleutherine bulbosa (UEB) bulbs from the Iridaceae family. This plant has been used for ethnobotany boils drugs and has been known to have antibacterial activity toward against intestinal pathogen bacteria that is anaerobic Gram Negative, but still unknown its activity against on oral pathogenic bacteria such as $P$. gingivalis. The purpose of this study was to know the effect of UEB extract on the growth of $P$. gingivalis bacteria as in vitro. UEB is taken from agriculture center in Samarinda city. UEB Simplicia was tested for antibacterial activity using Kirby-Bauer disc diffusion method on BHI-A media supplemented with vitamin K and hemin. The bacteria which used were P. gingivalis ATCC® 33277. Blank disc $6 \mathrm{~mm}$ with nine concentrations attached to BHI-A medium, incubated for 24 hours at $37{ }^{\circ} \mathrm{C}$ in an anaerobic atmosphere, then sprayed MTT (3-[4,5-Dimethylthiazole-2-yl]-2,5diphenylttetrazoliumbromide) reagent and read a few moments later. For comparison, then used Chlorhexidine gluconate (CHX) $2 \mathrm{mg} / \mathrm{ml}$. The statistical analysis with t-test and there was significant different if $\mathrm{p}<0.05$. The result showed that the higher concentration of UEB ethanol extract will increase the growth inhibition zone of $P$. gingivalis bacteria and reach maximum at $10 \mathrm{mg} / \mathrm{ml}$ concentration. The result of $t$-test showed no difference significant of $P$. gingivalis bacterial inhibition zone in the treatment group of $10 \mathrm{mg} / \mathrm{ml}$ concentration on CHX $2 \mathrm{mg} / \mathrm{ml}$. This study proves UEB ethanol extract can inhibit the growth of $P$. gingivalis bacteria.
\end{abstract}

Keywords: Eleutherine bulbosa, Prophyromonas gingivalis, Inhibition Zone, Antibacterial Agents, Periodontitis 
Submitted on: 3 January 2018

Accepted on: 7 June 2018

DOI: https://doi.org/10.25026/jtpc.v4i3.151

\section{INTRODUCTION}

Periodontal disease is teeth and mouth diseases that is often suffered by humans. Periodontitis is one of periodontal disease, where there is inflammation of the dental support tissue, the main cause of specific bacteria in sub gingival plaque. Sub gingival plaques bacteria may cause an inflammatory response to the gingiva and continue to the structure of the dental support tissue are the alveolar bone, the periodontal ligament and the cementum. This condition causes the loss of attachment on gingiva and alveolar bone damage, periodontal pocket formation and mobility on the teeth $[1,2]$.

The number of periodontal deviation in the world and Indonesia are quite high. World Health Organization (WHO) states that periodontal diseases case in the world approximately $10 \%$ from $15 \%$ population with pocket depth more than $2 \mathrm{~mm}$ [3]. Periodontal prevalence reaches around $37.4 \%$ by adults with loss of attachment more than 3 $\mathrm{mm}$ for $37.4 \%$ from adults who are affected by periodontal disease aged more than 30 years. The prevalence loss of attachment more than $4 \mathrm{~mm}$ about $10.6 \%$. Periodontal disease gets second rank after dental caries [4]. According to the Basic Research Health in 2013, dental and oral health problems in Indonesia reached 25.9 $\%$ of the total population.

Prophyromonas gingivalis $(P$. gingivalis) is an anaerobic bacterial obligat Gram Negative that becomes the cause of periodontitis bacteria. The bacteria found more than $85 \%$ of people with periodontitis. Periodontal tissues damage is closely related to virulence of
$P$. gingivalis bacteria by increasing bacterial colonization and bacterial invasion into host cells, and it can damage the host cells by producing endotoxins (LPS), collagenase enzymes, fibrinolysis, protease enzymes, and induction of inflammatory mediators [6].

Treatment of periodontitis can be focused on decreasing the number of bacteria with antibacterial agents. Antibacterial agents may come from chemicals or plants. The plants that have antibacterial effects can be used as an alternative treatment because it is considered more secure. Dayak Onions with the Latin name Eleutherine bulbosa (Mill.) Urb. (E. Bulbosa) from the Iridaceae familiy, there are many Dayak Onions in Kalimantan. The observation result of ethnobotany, the tuber is used by Dayak ethnic in Kalimantan as medicine for boils. All tubers have beneficial because they contain compounds of naphtaquinons, flavonoids, tannins, and alkaloids that are proved have antibacterial effects. Bulbs E. bulbosa has been shown to have an antibacterial effect on intestinal pathogen bacterial Escherichia coli (E. coli) which is an anaerobic Gram Negative bacterial [8], but the activity has not been known through bacteria $P$. gingivalis. The bacteria of $P$. gingivalis belong to anaerobic Gram Negative bacterial such $E$. coli so it can be inhibited by $E$. bulbosa. The aim of this research is to know the E. bulbosa extract towards bacteria growth of $P$. gingivalis in vitro.

\section{EXPERIMENTAL SECTION}

This research is an experimental laboratory, the research design uses the 
post test only control group. Test of bacterial inhibition zone that is used Kirby-Bauer disc diffusion method. The research protocol has been agreed by The Commission of Ethics Research Faculty of Medicine Mulawarman University.

\section{Material and Equipment}

This research used Brain Heart Infusion Agar media (BHI-A) and Brain Heart Infusion Broth (BHI-B) from Oxoid $^{\mathrm{TM}}$ that has been supplemented by vitamin $\mathrm{K} 0.5 \mu \mathrm{g} / \mathrm{ml}$ and hemin $5 \mu \mathrm{g} / \mathrm{ml}$ (Hemin Chloride from MP Biomedicals, Inc.) [9], blank disc from Oxoid ${ }^{\mathrm{TM}}$ with diameter $6 \mathrm{~mm}$, Prophyromonas gingivalis $\mathrm{ATCC}^{\circledR} 33277$ from Oxoid ${ }^{\mathrm{TM}}$, CHX $2 \mathrm{mg} / \mathrm{ml}$ from MINOSEP ${ }^{\circledR}$, etanol 96\%, 3-[4,5-Dimethylthiazole-2-yl]-2,5diphenylttetrazoliumbromide (MTT), disposable sterile petri dish from Thermo Scientific ${ }^{\mathrm{TM}}$, rotary evaporator, filter paper of Wathman ${ }^{\circledR}$ no.42, digital caliper from $\quad$ TRICLE BRAND $^{\circledR}$, spectrophotometry, anaerobic jar, cotton swab sterile, and aquadest sterile.

\section{Extraction and Sample Preparation}

This research used E. bulbosa bulbs that have taken from agriculture central in Samarinda and it has been identified by taxonomy expert from Anatomy laboratory and systematics plantation from Faculty of Mathematics and Science, Mulawarman University. Herbarium saves in Pharmacology with Voucher number: EB 01/VI/2017. The dried E. bulbosa bulbs is macerated with 96\% ethanol solvent for 3 days. The maceration results are filtered using by Whatman ${ }^{\circledR}$ no. 42 filter paper and filtrate is concentrated with rotary evaporator with the temperature about $50{ }^{\circ} \mathrm{C}$ until being crude extract and thick. The concentrated extract is further dried inside the oven with $60{ }^{\circ} \mathrm{C}$ until the moistures content $<10 \%$.

\section{Kirby-Bauer disc diffusion Method}

The research is done with three stages. First stage is preparation of suspension bacteria of $P$. gingivalis. Bacteria is cultured by using BHI-B media that has been supplemented with vitamin $\mathrm{K} \quad 0.5 \mu \mathrm{g} / \mathrm{ml}$ and hemin $5 \mu \mathrm{g} / \mathrm{ml}$. $P$. gingivalis bactreria that is used with concentrated from McFarland 0.5 or same have equivalent with $1.5 \times 10^{8} \mathrm{CFU} / \mathrm{ml}$ [10].

The second stage is disc diffusion disc. Blank disk is being dropped by extracting E.bulbosa with last concentration $0.1,0.25,0.5,0.75,1,2.5$, $5,7.5$, and $10 \mathrm{mg} / \mathrm{ml}$ as controller that is used for CHX $2 \mathrm{mg} / \mathrm{ml}$, and ethanol $96 \%$ (extract solvent). The disc is dried in a temperature about $60{ }^{\circ} \mathrm{C}$ oven for 5 minutes to vaporize the rest of the solvent. The total of $100 \mu \mathrm{l}$ of bacterial suspension is uniformly removed on the surface of BHI-A media for supplementation of vitamin $\mathrm{K} 0.5 \mu \mathrm{g} / \mathrm{ml}$ and hemin of $5 \mu \mathrm{g}$ $/ \mathrm{ml}$. Disc extracts of various concentrations of E. bulbosa, CHX 2 $\mathrm{mg} / \mathrm{ml}$ and $96 \%$ ethanol are placed on the agar plate which has been inoculated with bacteria. Incubate at $37{ }^{\circ} \mathrm{C}$ for 24 hours under anaerobic atmosphere inside the anaerobic jar. The Visualization of the inhibit zone is easier by spraying the MTT reagent on the plate as evenly and then read the results a moment later. The last stage in this research is the measurement of diameter of inhibit zone by using digital calliper. Inhibit zone that is measured is a clear zone around the disc. The measurement of inhibit zone is done both horizontal and vertical then they were averaged.

\section{Analysis Data}

The data is presented in mean \pm SEM. The data analysis used SPSS 22. The statistics measurement with t-test and different meaning if the result is $<0.05$. 


\section{RESULT AND DISCUSSION}

The result of the research showed that there are diameter of inhibit zone in all groups of E. bulbosa extract and CHX $2 \mathrm{mg} / \mathrm{ml}$ through bacteria of $P$. gingivalis that has been shown on a Table 1. The higher concentration of E. bulbosa extract tested, it also will result in higher diameter of the inhibit zone.

Table 1. Diameter of inhibit zone of E. bulbosa and CHX $2 \mathrm{mg} / \mathrm{ml}$ towards $P$. gingivalis bacteria

\begin{tabular}{ccc}
\hline Concentration $(\mathrm{mg} / \mathrm{ml})$ & Diameter of inhibit zone $(\mathrm{mm})$ & $P$ \\
\hline 0.1 & $6.2 \pm 0.2$ & $0.000^{*}$ \\
0.25 & $6.3 \pm 0.3$ & $0.000^{*}$ \\
0.5 & $6.5 \pm 0.4$ & $0.000^{*}$ \\
0.75 & $6.8 \pm 0.4$ & $0.000^{*}$ \\
1 & $7.7 \pm 0.5$ & $0.000^{*}$ \\
2.5 & $9.5 \pm 0.5$ & $0.000^{*}$ \\
5 & $10.9 \pm 0.6$ & $0.020^{*}$ \\
7.5 & $12.7 \pm 0.4$ & 0.087 \\
10 & $14.3 \pm 0.1$ & 0.160 \\
CHX 2 & $13.7 \pm 0.3$ & - \\
\hline
\end{tabular}

Notes: Seven times repetitions. The data is presented in mean \pm SEM. Disc diameter approximately $6 \mathrm{~mm}$. CHX $=$ Chlorhexidine gluconate. $*$ Statistical test with t-test compared with $\mathrm{CHX}$, it significantly different if $\mathrm{p}<0.05$.

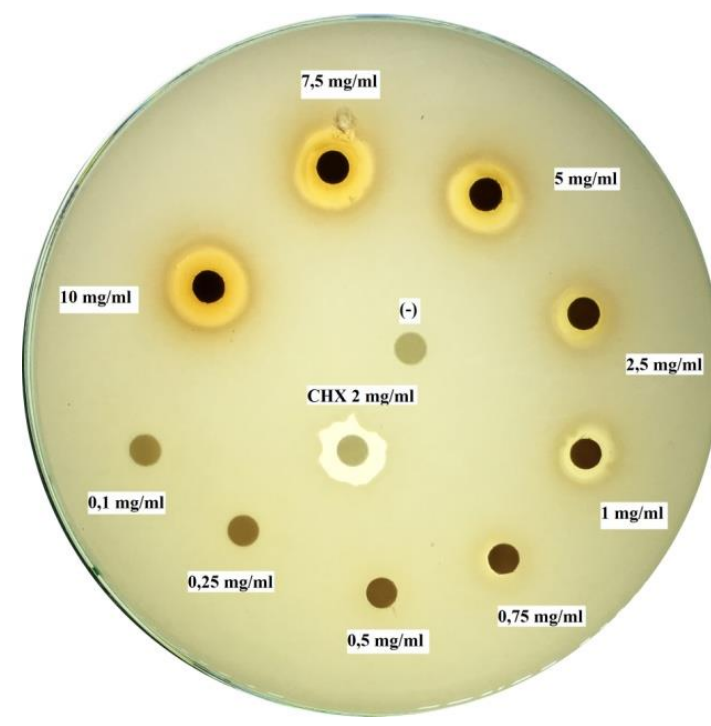

BEFORE

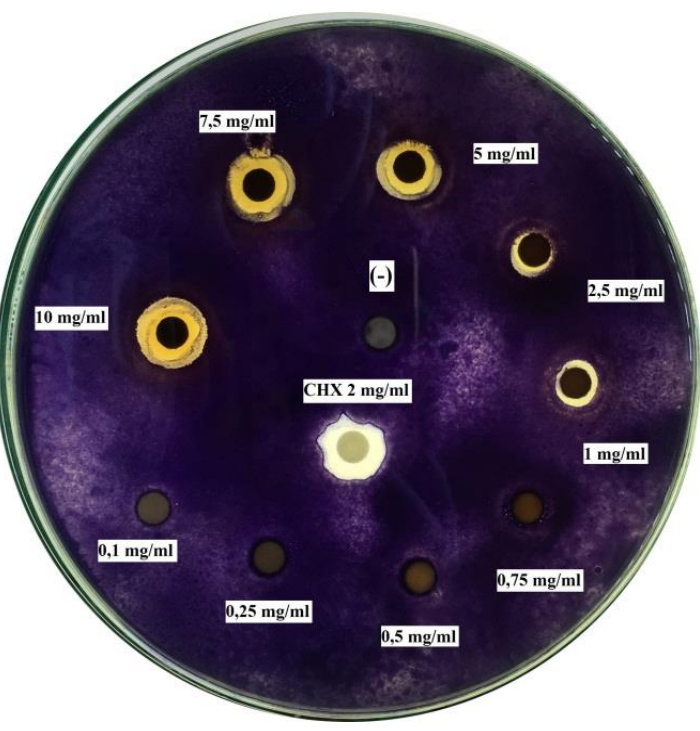

AFTER

Figure 1. The inhibit zone of bacteria extract of E. bulbosa, CHX $2 \mathrm{mg} / \mathrm{ml}$, etanol $96 \%$ towards $P$. gingivalis bacteria before and after spreading with MTT. Note: $\mathrm{CHX}=$ Chlorhexidine gluconate, MTT= 3-[4,5-Dimethylthiazole-2-yl]2,5-diphenylttetrazoliumbromide. 
The measurement of inhibit zone in negative control of ethanol about $96 \%$ $(\mathrm{KN})$ that is used in this research do not indicate a bacterial of inhibit zone, or produces in a diameter of inhibit zone that have equivalent with disc diameter about $6 \mathrm{~mm}$ (Figure 1). In a positive control of CHX $2 \mathrm{mg} / \mathrm{ml}$ is gotten inhibition zone $13.8 \pm 0.4 \mathrm{~mm}$ (Tabel 1). The research result shows that there are diameter of inhibit zone bacteria in all extract concentrations that are measured. This argument also is supported by the research that is done by Padhi and Panda (2015) whom stated that an inggredient has antibacterial effect if inhibit zone diameter more than disc diameter about $6 \mathrm{~mm}$ [8].

The strength determination of antibacterial effect with disc diffusion method is interpreted with David and Stout's criteria in 1971, this criteria divided into 4 strength antibacterial effect based on diameter of inhibit zone that is formed after incubation period. The criteria such as the activity of antibacteria low if inhibit zone diameter around 1-4 $\mathrm{mm}$, meanwhile if inhibit zone diameter about 5-10 $\mathrm{mm}$, strong if it has inhibit zone diameter approximately 11-20 mm and very strong if it has inhibit zone diameter around $>20 \mathrm{~mm}$. Strength interpretation of antibacterial effect is done after forming inhibit zone minus with disc diameter. In this research, $E$. bulbosa extract has concentration 0.1, $0.25,0.5,0.75,1$, and $2.5 \mathrm{mg} / \mathrm{ml}$ and low activity antibacterial, but concentration among 5, 7.5, and $10 \mathrm{mg} / \mathrm{ml}$ have medium antibacterial activity [11].

The result of this research dercribes that the increasing of E.bulbosa concentration is directly propotional with the increasing of the inhibition zone of bacteria. It shows that antibacterial activity increase with the existance of E.bulbosa concentration. The increasing of extract concentration also improve the amount of secondary metabolities that have role in actibacterial activities. The secondary metabolities have antibacterial effect in E.bulbosa extract are naphtaquinone, alkaloids, tanin, flavonoid [7].

Ifesan et al. in 2009 reported that the ingredient of naphtaquinone in E.bulbosa can inhibit the bacterial growth, it is associated with cytoplasmatic leakage and it caused the damage to the bacterial cell membranes [12]. Flavonoids have antibacterial effects through the mechanism of action damage to the premeability of bacterial cell walls, inhibit protein synthesis, and energy metabolism $[13,14]$. Alkaloids have antibacterial effects through mechanisms action to lyse bacteria, alter bacterial cell morphology, inhibit ion channels and bacterial DNA synthesis [15]. Tanin proves have the antibacterial effect through a very complex mechanism action, for example deactivating bacterial adhesion, inhibiting the reverse transkriptase enzym, DNA topoisemerase, inhibiting cell transport so the bacterial cell can not be formed [14].

E. bulbosa have some secondary metabolities that have been mentioned above, all metabolities have antibacterial effect. The antibacteria effect that exists in E.bulbosa extract have possibility caused by some of secondary metabolities, so the mechanism is not specific from the secondary metabolities compound, but antibacterial effect of $E$. bulbosa extract have mechanism action that involve some of targets in bacteria cells, for instance it causes of damage sitoplasm membran, bacterial adhesi, electron transport, active transport and synthesis DNA $[12,13,14,15]$. It needs more research about antibacteria mechanism in each compounds of secondary metabolities towards the development of $P$. gingivalis which synergystic or non-synergistic. 


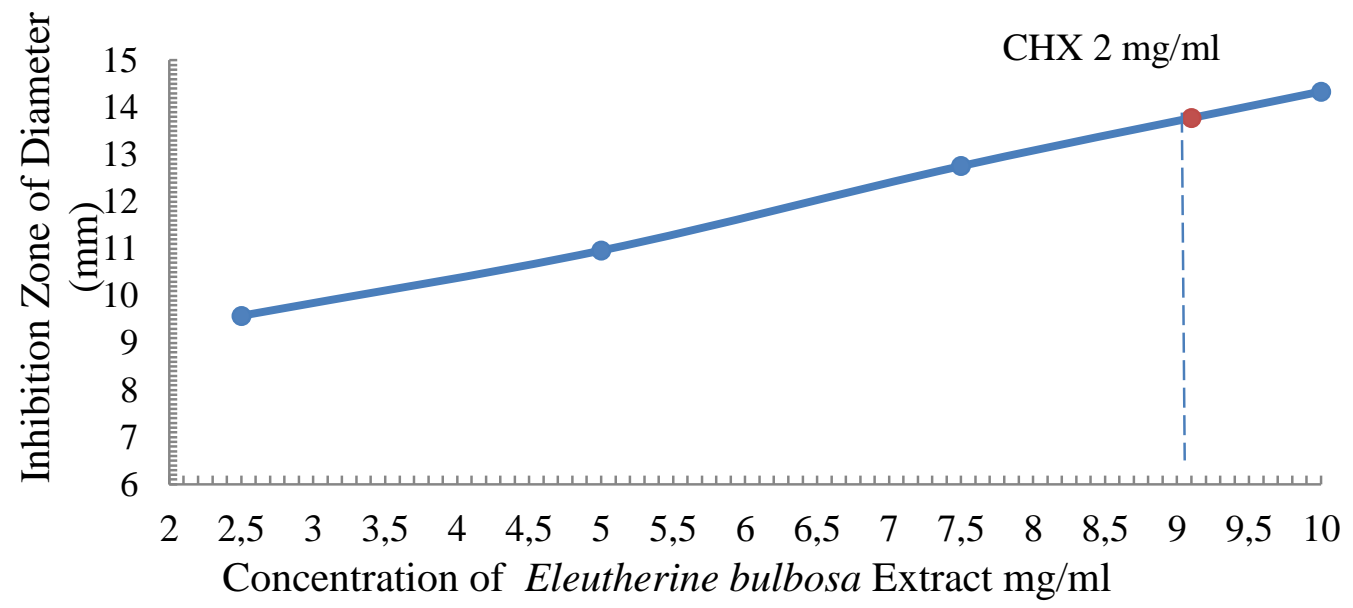

Figure 2. The Curve of concentration extract of E. bulbosa and CHX $2 \mathrm{mg} / \mathrm{ml}$ with inhibit zone bacteria

Note: $\mathrm{CHX}=$ Chlorhexidine gluconate

The statistical measurement with ttest shows that in E. bulbosa concentration $0.1,0.25,0.5,0.75,1,2.5$, and $5 \mathrm{mg} / \mathrm{ml}$ towards CHX $2 \mathrm{mg} / \mathrm{ml}$ there are meaningful differences with the result of $p<0.05$. In concentration of 7.5 and 10 $\mathrm{mg} / \mathrm{ml}$ through CHX $2 \mathrm{mg} / \mathrm{ml}$ there are no meaningful differences with the result of value $\mathrm{p}=0.087$ and 0.160 (Table 1 ).

The research that was done by Ifesan et al. in 2010 results that E. bulbosa extract more effective to inhibit the bacterial growth of Gram Positive more than Gram Negative bacteria, the research used concentration of $2.5 \mathrm{mg} / \mathrm{ml}$ and it do not get inhibit zone on an anaerobic bacteria Gram Negative [16]. This research gets results that $E$. bulbosa with concentration around $2.5 \mathrm{mg} / \mathrm{ml}$ have an anaerobic inhibition zone of Gram Negative bacteria $P$. gingivalis. This statement also is supported with the research that was done by Padhi and Panda in 2015 claimes that E. bulbosa extract with $30 \mathrm{mg} / \mathrm{ml}$ concentration presents the diameter of inhibit zone on the anaerobic Gram Negative Bacteria. Gram Negative bacteria has more complex structure on wall complex more than Gram Positive bacteria. Gram Negative bacteria have an outer membrane that surrounds the cell wall, this is may cause Gram Negative bacteria to be more resistant through antibacterial action [8].

The diameter of extract inhibition zone of E. bulbosa with concentration $0.1,0.25,0.5,0.75,1,2.5,5$, and 7.5 $\mathrm{mg} / \mathrm{ml}$ smaller than inhibition zone from CHX $2 \mathrm{mg} / \mathrm{ml}$. The diameter of inhibition zone E. bulbosa ex tract with concentration approximately $10 \mathrm{mg} / \mathrm{ml}$ bigger than inhibition zone from CHX $2 \mathrm{mg} / \mathrm{ml}$ (Table 1). The research that was done by Ferraz et al. in 2007 about antibacterial effect of CHX $2 \mathrm{mg} / \mathrm{ml}$ towards $P$. gingivalis produces diameter of inhibit zone bacteria about $11.17 \mathrm{~mm}$, if it compared with this research that diameter of inhibit zone bacteria that is formed by CHX $2 \mathrm{mg} / \mathrm{ml}$ through $P$. gingivalis produces diameter of inhibit zone about $13.77 \mathrm{~mm}$ [17].

The regression result of the effectivity of $E$. bulbosa extract equal with $\mathrm{CHX} 2 \mathrm{~m} / \mathrm{ml}$ in concentration 9.1 $\mathrm{mg} / \mathrm{ml}$ (Figure 2). $\mathrm{CHX}$ is an antibacterial 
broad-spectrum that is gold standard to oral hygine. $\mathrm{CHX}$ is used to inhibit bacteria growth of $P$. gingivalis that causes of periodontal disease [1]. CHX prevents plaque formation on teeth, but this mouthwash is reported have local effects. CHX in long-term use has side effect such as dyeing brown teeth, having unpleasant taste, oral mucosal ulceration, parasthesis, sweeling of parotid gland and increasing the formation of supragingival calculus [18].

\section{CONCLUSION}

Etanol extract of E. bulbosa proves have inhibition of development effect of $P$. gingivalis bacteria, the existance of inhibit zone bacteria that is formed around disc, the higher concentraton extract that is measured will also higher the inhibition zone bacteria through concentration of 9.1 $\mathrm{mg} / \mathrm{ml}$ that activity is equal with $\mathrm{CHX} 2$ $\mathrm{mg} / \mathrm{ml}$.

\section{ACKNOWLEDGMENT}

The researcher gives thanks to the Head of Laboratory Farmachology, Faculty of Medicine in Mulawarman University and Oral Biology Laboratorium of Oral Dentistry Study Programe Faculty of Medicine Mulawarman University that has given the facilities to this research and Mrs. Yunie Safitri, S.Si who helped me a lot in this research.

\section{REFERENCES}

[1] Nair, S., \& Anoop, K. 2012. Intraperiodontal pocket: An ideal route for local antimicrobial drug delivery. Journal of Advanced Pharmaceutical Technology \& Research, 3(1), 9-15. doi: $\underline{10.4103 / 2231-4040.93558}$
[2] Langlais, P. 2013. Atlas Berwarna Lesi Mulut yang Sering Ditemukan, 4th ed., Rasyad EM, editor, Jakarta: EGC

[3] Petersen, E., \& Ogawa, H. 2012. The Global Burden of Periodontal Disease: Towards Integration With Chronic Disease Prevention and Control, Periodontology 2000, 60(1), 15-39. doi: 10.1111/j.16000757.2011.00425.x

[4] Eke, P., Dye, B., Wei, L., Slade, G., Thornton-Evans, G., Borgnakke, W,. Taylor, G., Page R., Beck, J., \& Genco, R. 2015. Update on Prevelence of Periodontitis in Adults in the United State: NHANES 2009 to 2012. Journal of Periodontology, 86(5), 611-622. doi: 10.1902/jop.2015.140520.

[5] Badan Pengembangan dan Pembangunan Kesehatan. 2013. Riset Kesehatan Dasar, RISKESDA 2013, Jakarta: Kementrian Kesehatan RI.

[6] Mysak, J., Podzimek, C., \& Sammerova, L. 2014. Review Articel Prophyromonas gingivalis: Major Periodontopathic Pathogen Overview, Journal of Immunology Reaserch, 55-62. doi: 10.1155/ 2014/476068.

[7] Puspadewi, R., Adirestuti, P., \& Menawati, R. 2013. Khasiat Umbi Bawang Dayak (Eluetherine palmifolia (L.) Merr) Sebagai Herbal Antimikroba Kulit, Kartika Jurnal ILmiah Farmasi, 31-37.

[8] Padhi, L., \& Panda, S. 2015. Antibacterial Activity of Eleutherine bulbosa Againts Multidrug Resistant Bacteria, Journal of Acute Medicine, 5(3), 53-61. doi: 10. 1016/j.jacme.2015.05.004 
[9] Henry, L., Aruni, W., Senbreg, L., \& Fletcher, H. 2013. Proctetive Role of the PG1036-PG1038 Operonin Oxidative Stress in Prophyromonas gingivalis W83, PLOS ONE, 8(8), e69645 1-14. doi: 10.1371/journal.pone.0069645.

[10] Clinical and Laboratory Standards Institute. 2012. Performance Standards for Antimicrobial Disc Susceptibility Test; Approved Standard-Eleventh Edition, CLSI Document M02-A11, Wayne: Author. Available form https://clsi.org [Accesed 2017 July 23].

[11] Davis, W., \& Stout, T. 1971. Disc Plate Method of Microbiological Antibiotic Assay: Factor Influencing Variability and Error. Applied Microbiology, 22(4), 659665. Available form https://www.ncbi.nlm.nih.gov/m/pu mbed/5002143/ [Accessed 2017 July 23].

[12] Ifesan, B., Jaycharat, N., \& Voravuthikunchai, S. 2009. The Mode of Antistaphylococcal Action of Eleutherine americana, FEMS Immunol Med Microbial, 57, 193201. doi: 10.1111/j. 1574695X.2009.00599.x.

[13] Kumar, S., \& Pandey, A., K. 2013. Chemistry and Biological Activities of Flavonoids: An Overview. The Scientific World Journal, 2013, 116. doi: 10.1155/2013/162750.
[14] Cushnie, T., \& Lamb, A. 2005. Review Antimicrobial Activity of Flavonoids. International Journal of Antimicrobial Agents, 26, 343-356. doi: $10.1016 / \mathrm{j}$. ijantimicag.2005.09.002.

[15] Cushnie, T., Cushnie, B., \& Lamb, A. 2014. Alkaloids: An Overview of their Antibacterial, Antibioticenchancing and Antivirulence Activity, International Journal of Antimicrobial Agents, 44(2014), 377-386. doi: 10.1016/j.ijantimicag.2014.06.001.

[16] Ifesan, B., Ibrahim, D., \& Voravuthikunchai, S. 2010. Antimicrobial activity of crude ethanolic extract from Eleutherine americana, Journal of Food, Agriculture \& Environment, 8, (3\&4), 1233-1236. Available form https://world-food.net [Accesed 2017 June 13].

[17] Ferraz, C., Gomes, B., Alexander, Z., Teixeria, F., \& Souza-Filho, F. 2007. Comparative Study of the Antimicrobial Efficacy of Clorhexidine Gel, Clorhexidine Solution and Sodium Hypochlorite as Endodontic Irrigants, Braz Dent $J$, 18(4), 294-298. Available form https://www.ncbi.nlm.nih.gov/m/pu bmed/18278298/ [Accesed 2017 July 20].

[18] Anggayanti, N., Adiatmika, I., \& Adiputra, N. 2013. Berkumur dengan Teh Hitam Lebih Efektif dari pada Clorhexidine Gluconate 0,2\% untuk Menurunkan Akumulasi Plak, Jurnal PDGI, 62, 35-34.

How to cited this article:

Azizah, S.N., Yani, S., Ismail, S., Masyhudi, Sawitri, E., 2018. Effect of Ethanol Extract of Eleutherine bulbosa (Mill.) Urb on Anaerobic Bacterial Prophyromonas gingivalis in vitro. J. Trop.Pharm. Chem. 4(3); 128-135. 